KOLESNYKOVA T. O.

Scientific and Technical Library, Dnipro National University of Railway Transport named after Academician V. Lazaryan (Dnipro, Ukraine), e-mail lib@b.diit.edu.ua, ORCID 0000-00024603-4375

\title{
THE ROLE OF LIBRARIES AS PUBLISHERS IN THE OPEN EDUCATION LANDSCAPE: REFLECTING MODERN WORLD PRACTICE OF OPEN TEXTBOOKS
}

Objective. The study aims to analyse the experience of university libraries in different countries in working with the Open Textbook (OT) and to consider the prospects of creating a similar pilot project in Ukraine. Methods. The analysis covered the world publications (journals, books, conference proceedings, posts on social networks) in the field of Library and Information Science, devoted to the role of libraries in OT support, that have appeared since 2014. The author studied the aspects revealing that publication, namely OT, support services are areas with great potential for the future development of academic / university libraries. Results. Numerous evidence is presented that the topic of library as a publisher in OT support is most developed in the universities and colleges in economically developed countries, especially in the USA, Canada, Australia, and Great Britain. Library strategies for OT projects have been identified. The author clarified the nature of the initiatives and partnerships of libraries in supporting OT, as well as the basic services and roles of libraries in these projects. Conclusions. Today, the global practice of Scholarly Communication has enough evidence that the functions of the Library, lost in the course of evolution, as a Knowledge Publisher have returned under its "roof" and supplemented the existing function of Knowledge Managers. Digital Library Publishing (DLP) services in OT support help to change the learning environment and life of students (including persons with disabilities), pedagogical practices of teachers by means of free textbooks with an open license, as well as to receive reputation benefits for the university, improving the image of the latter. The possibility of eliminating systemic inequalities in access to academic resources increases the significance and changes the role of libraries in open education. The successes of Ukrainian librarians in supporting digital scholarly communication initiatives and the successful implementation of Open Access support projects (repositories, ejournals, e-conferences) give confidence that they can act as initiators and key partners in creating affordable textbooks.

Keywords: Open Textbook; textbook affordability; open education; library as publisher; services; Digital Library Publishing; university libraries; Ukraine

\section{Introduction}

The development of a knowledge society, the widespread dissemination of information technologies create not only new opportunities for learning. They also challenge established views and practices regarding how teaching and learning should be organised and carried out.

The wider context of a culture of open knowledge, open source, free sharing and peer collaboration, which emerged in the late 20th century, is characterized by the formation of the global movement Open educational resources (OER) for the development of open and distance learning.

OER can be separated by content type into four groups: text-led, video-led, animation-led and multiple media. Types of OER include: full courses, course materials, modules, learning objects, open textbooks, openly licensed (often streamed) videos, tests, software, and other tools, materials or techniques used to support access to knowledge (Butcher \& Moore, 2015, p. 34). According to the Legislation of Ukraine "On Approval of the Provision on Electronic Educational Resources" (Ministry of Education and Science, Youth and Sports of Ukraine, 2012), in terms of the functional characteristics of OER in the educational process, they are divided into electronic educational publications (including textbooks, work-books, lecture courses, etc.), electronic reference books and electronic practical publications. 
Thus, Open Textbook (OT) is one of the significant components of OER, expanding access to education and supporting innovations in teaching and learning. The notion of "Digital textbooks" (Digital textbook, 2019) reveals them as the major component of technology-based education reform. They may serve as the texts for a traditional face-to-face class, an online course or degree, or massive open online courses (MOOCs).

But, even after almost 20 years since the advent of OER, educational information exchange systems still do not meet the potential of the 21st century technologies, although the whole world is striving for new educational opportunities. The Scholarly Publishing and Academic Resources Coalition Europe (SPARCEurope) website (2019) notes that the global educational materials market is supported by outdated publication models that significantly limit the distribution and innovative use of resources.

In the context of constantly increasing prices for educational services and the cost of textbooks at universities around the world, the affordability of higher education is becoming increasingly difficult. For example, according to the data of the World Bank Country and Lending Groups in 2019, 31 countries had income in economic indicators of GDP per capita below the average - \$1,026 to \$3,995 (The World Bank, 2019). Lower middle-income countries include Ukraine as well. In addition, in Ukraine, which has 19 universities that were displaced in 2014 from the temporarily occupied territories of Donetsk and Lugansk regions, as well as the Autonomous Republic of Crimea, the situation with providing libraries and bookstores with modern textbooks is especially tense.

In an effort to adequately follow their mission to promote the creation of knowledge, their preservation and dissemination, university libraries of different countries make a significant contribution to the digitalization of education and science. Following their focused communication strategies, libraries join actively in a wide range of digital scholarship events (Kolesnikova, 2014; Kolesnykova \& Kliushnyk, 2015; McGrath, 2018; McCready \& Molls, 2018; Raju, 2016; Schmolling, 2015). At the same time, they get themselves noticed not only as owners of digital collections and service providers, but also as reliable partners in the publishing of knowledge - Digital Library Publishing (DLP).

In addition, the pursuance of social justice is part of the mission of libraries. Therefore, the possibility of eliminating systemic inequalities in the availability of academic resources motivates librarians to constantly look for new ways and initiate new projects in the development of open scholarly and educational resources, including the creation and use of Open Textbook.

\section{Literature review}

In the process of evolution, the Library as a social institution has undergone significant changes. From a once functionally triune institution (Volodin, 2002), uniting under one "roof" knowledge creators, knowledge publishers, knowledge managers (that is, people responsible for the availability of acquired knowledge, its dissemination and preservation for subsequent generations), it was entrenched for many centuries mainly with only the function of collecting, organizing, storing literature and its lending to readers (Kolesnikova, 2014). As a result of the bifurcation of communication channels, the library ceased to fulfill the function of a scriptorium (copy manufacturer), which was fundamentally important to it for the past millennium. With the development of book printing, the function of book production was completely separated from the function of collecting and storing books, and printing and publishing houses became the institutions separate from the library.

But at the beginning of the XXI century, as a result of the technological boom, university libraries were again included in the provision of new publishing channels. The collaboration environment initially involved primarily digitizing of old publications, promoting of open access, and increase in publishing services for informal scientific publications - gray literature (Watkinson, 2014). Further library work with institutional repositories was supplemented by support for electronic academic journals and books deployed on the open platforms DSpace, 
Open Journal Systems, Open Monograph Press, etc. (Pitcher, 2014; Kolesnykova \& Kliushnyk, 2015).

Today, Digital Library Publishing (DLP) services, supporting the communities of their universities and colleges in the development, creation, management and distribution of online publications, including OER and OT, successfully operate in different countries (Schmolling, 2015; McGrath, 2018).

And the movement for the creation and distribution of Open Textbook itself is becoming increasingly popular, because OTs are complete, true textbooks that are used by many teachers and licensed for free use, editing and distribution. Generally, legal permission is granted by use of an open license (for example, Creative Commons license) which allows anyone to freely use, adapt and share the resource - anytime, anywhere (SparcEurope, 2019).

OT can be either digital or printed. Since authors and publishers almost always provide PDF for printing as needed, students can print the entire textbook or the required number of pages.

The popularity of OT is also due to the growing negative consequences in the academic performance of students, who are often forced to refuse a purchase of expensive books and complete course attendance (Open Textbooks Matter, n.d.). Research in a number of US colleges shows that students spend an average of \$ 900-1,200 each year on textbooks, but these costs continue to grow every year (Open Textbooks Matter, n.d.; Allen, 2010).

For example, Nicole Allen (2010) published data showing that an average student in Chicago spends \$ 900 on textbooks per year, which is $26 \%$ of average education in a university and $76 \%$ of average education in a college. Public Interest Research Groups (PIRG) of students conducted groundbreaking research in 2010 by interviewing 1,428 college students at ten campuses to find that open textbooks can help students cut costs and save up to $80 \%$.

The U.S. government has initiated grants to transform textbooks that have been provided to teachers, libraries and librarians to increase access to education (Croteau, 2017). Grants allocated by the budget in the state of Georgia already at the first stage showed their effectiveness, as they allowed the students to save about 760000 dollars without negative impact on learning outcomes.

The timeliness and importance of including libraries in Open Textbook publishing are supported by evidence of a reduction in the financial burden on students using such publications. For example, the Rhode Island College Adams Library on September 18, 2019 notes that "Students at RIC saved \$143,600, this semester, and \$594,700, since 2016 in textbook costs through faculty adoption of open textbooks and open educational resources!” (Open Textbook Network, n.d.).

And the website of Charles C. Sherrod Library East Tennessee State University (2019) gives the data that over the year the library helped save $\$ 200,000$ to students at its university through OER initiatives.

Library plans and OT activities that reduce student textbook costs and increase academic activity may vary. Ranging from defining strategies (Thomas \& Bernhardt, 2018), financial support for teachers, implementing individual creative projects to increase the interest of teachers and students, and to training programs for librarians.

For example, the Oregon State University (OSU) Libraries launched a program in 2013 that provided a scholarship of US \$ 15,000 for OSU teachers (through a budget) to publish an open textbook. The competitive application process emphasized "the use of rich, original multimedia and interactive content” (Sutton \& Chadwell, 2014, p. 41).

University Libraries at Virginia Tech, by popularizing and raising awareness of free and open educational opportunities that exist for everyone, everywhere and now, have created a number of popular videos (VTLibraries, 2016). 
In an effort to expand interest in creating and using the OT the University of Kansas Libraries, in collaboration with the Shulenburger Office of Scholarly Communication \& Copyright in May 2019 announced Textbook Heroes, a new initiative spotlighting KU faculty, staff, instructors and students who advocate for textbook affordability. Textbook Heroes are identified among those who have adapted, adopted, created or championed open educational resources (OER) and other low-cost materials for use in classrooms at KU (KU Libraries, 2019).

As the use of OER in education and research continues to grow, there is an increasing need for specific methods for developing, supporting, and deploying OER as part of library publishing programs, including the scope of services and staffing requirements (McCready \& Molls, 2018).

Training programs for librarians implementing publishing projects are provided, for example, by Library Publishing Coalition: Library Publishing Curriculum (Lippincott, Schlosser, Ballard, \& Maron, 2018) and a series of webinars for professional development (Library Publishing Coalition. (n.d.).

Rhode Island College Adams Library (2019) organizes “Open Textbook Workshop”, for librarians, teachers and students, where they teach OT practices and provide teachers with content that can be adapted to their courses.

With over 100 members (universities, university libraries and colleges in the USA), the Open Textbook Network provides formal training for librarians under "The Certificate in OER Librarianship” program (Open Textbook Network, 2019). This is the program of professional development that creates effective managers of open education projects who want to be stewards and advocates of open educational resources.

The results of the study of the Open and Affordable Textbooks program at Rutgers University, USA, which is administered through libraries, complete the discussions on the need for library support for OT and call for defining an ecosystem of library services and activities that support affordability of textbooks and OER (Todorinova \& Wilkinson, 2019).

But at the same time, for university libraries in Eastern Europe and Ukraine, the topic of partnership with teachers, scientists and OER specialists in creating and using the Open Textbook is still not sufficiently covered and presented in publications.

Thus, the implementation of the Polish state program, which released open digital textbooks, at the first stage did not involve the use of library publishing services. But the guidance of A.Tarkowski, M. Sitek, J. Strycharz, R. Vuorikari \& J. Castaño Muñoz (2019) can help librarians further study the costs and savings associated with open textbook initiatives and assess their impact on the results of learning (e.g., based on academic achievement example) (Tarkowski, Sitek, Strycharz, Vuorikari, \& Castaño Muñoz, 2019).

In Ukraine, the topic of the library as a publisher of scholarly digital resources (repositories, e-journals, e-conferences, open access initiatives, related services) (Kolesnykova \& Kliushnyk, 2015; Kolesnykova, 2019; Levchenko, 2018) as well as the motivational factors for improving professional competencies of a university librarian in supporting open knowledge (Serbin \& Kulyk, 2019) are periodically addressed in LIS publications. But the author of this study has not found publications on the inclusion of libraries in Open Textbook projects.

The purpose of this study is to analize the experience of university libraries in different countries in working with the Open Textbook and to consider the prospects of creating a similar Ukrainian (international) pilot project.

\section{Methods}

The study is based on an analysis of world publications on Library and Information Science (journals, books, conference proceedings, posts on social networks) that have appeared since 2014. To search for publications, I used the databases Scopus, Web of Science, Google Scholar, social networks ResearchGate and Facebook, sites of selected journals, university 
libraries and professional communities (Library Publishing Coalition, SPARC Europe, The Association of College \& Research Libraries).

The search was conducted by the key phrases "open textbook and library support,“ academic libraries and textbook affordability", "library publishing and open textbook".

I analyzed the evidence that publishing support services, namely the Open Textbook, are areas with great potential for the future development of academic / university libraries.

In order to better understand the global landscape of DLP in the field of OT, before assessing the possibility of introducing such services in Ukraine, it was supposed to study the following aspects:

1) To clarify the services distribution scale in university libraries of the world.

2) To define library strategies for OT projects.

3) What is the nature of library initiatives and partnerships in supporting OT?

4) Library roles and basic services in OT projects

\section{Results and Discussion}

The study of professional literature and social network posts allows to state that technological innovations in the production and distribution of documents / information, problems of traditional publishing practices related to business models and intellectual property management, as well as active efforts to expand access to educational and scientific resources, have provided libraries with the opportunity to return the functions of knowledge publishers (once lost in the process of evolution).

The topic of library as a publisher in support of Open Textbook is most developed in the universities and colleges in economically developed countries, especially in the USA. American librarians study the successes and weaknesses of OT library projects in the context of: reducing students' financial costs; expanding affordability / receipt of texts; academic performance; developing partnerships with teachers, IT services and university press; the importance of competencies; common standards and workflows. Workshops and library trainings also often focus on Open Source Platforms (Open Monograph Press, Janeway, etc.). These are publishing systems for presenting manuscripts, managing peer reviews, editorial and production processes, information about books and hosting, as well as book distribution channels.

But at the same time, for countries with economic GDP indicators of low and middle income per capita, the experience of Libraries of the University of Cape Town, Republic of South Africa (Raju, 2016) and the Scientific and Technical Library of the Dnipro National University of Railway Transport may be interesting (Kolesnykova \& Kliushnyk, 2015; Kolesnykova, 2019).

University libraries, especially in the USA and Canada, are taking decisive steps to identify an ecosystem of library services and activities that support the availability of textbooks and OER. The programs administered through the Libraries offer a glimpse at how textbook affordability interfaces with key library services, including collection development, teaching and learning, reserves and the visibility, use and discoverability of library resources.

Two approaches are mainly used to develop and implement library support strategies for Open Textbook projects. The first approach involves material (as a rule, the provision of minigrants) and moral incentives for teachers who get involved in the processes to create OT, which will be free for their students. The second approach to the strategy is to identify the necessary texts that the library already owns or can acquire as e-books for an unlimited number of users. Herewith, it is especially important for a university (college) not only to respect copyright, but also to have publishing rights to a work. 
The initiatives and partnerships of libraries in support of Open Textbook are institutional in nature or are a joint venture.

Joint ventures bring together a number of institutions that share resources and a platform to reach a critical mass of freely accessible textbooks. In addition to the effect of significant cost savings and increased access to education, this makes it easier for beginners to publish open access electronic textbooks than starting from scratch on their own.

At the same time, some projects were more institutionally localized in nature at startup, and then expanded, accepting new participants and working more efficiently.

OT implementation projects are often two-stage, such as at the University of Minnesota Libraries (2019). At the first stage, implemented at the institutional level, the library conducts a range of activities from grant applications for teachers to assistance in the textbook production. On the second stage, it helps to load the text into the Open Textbook Library (http://open.umn.edu/). The similar work organization is at the State University of New York Libraries, supported by grants from SUNY Innovative Instruction Technology (https://textbooks.opensuny.org/about/), as well as librarians of the University of Minnesota Libraries, who state on the website that "We publish a number of journals, books, dynamic scholarly serials, and textbooks through our Libraries Publishing imprint” (University of Minnesota Libraries, 2019).

Joint ventures and popular tools to locate, create, and store open textbooks and resources are as follows:

- Open Textbook Library (http://open.umn.edu/). The library currently includes 680 textbooks, with more being added all the time. The Open Textbook Library is supported by the Center for Open Education and the Open Textbook Network;

- OER Commons (http://oercommons.org) - is a public digital library of open educational resources;

- Open Stax Connexions (http://cnx.org) - is a dynamic non-profit digital ecosystem;

- Merlot (Multimedia Education Resource for Learning and Online Teaching, http://merlot.org) - is an online repository and international consortium of institutions (and systems) of higher education, industry partners, professional organizations and individuals;

- BCcampus (https://open.bccampus.ca/) - contains BC Open Textbook Collection, OER by Discipline Directory, various tools and guides for creating OT;

- OASIS (Openly Available Sources Integrated Search, https://oasis.geneseo.edu/) - is being developed at SUNY Geneseo's Milne Library. It is used today as resource providers by almost 100 institutions in different countries (USA, Canada, Great Britain, Australia, Lebanon, Singapore, the United Arab Republic, etc.), which replenish therewith their subject collections;

- OER Commons (https://www.oercommons.org/). Digital librarians have curated collections of Open Textbooks and full courses to help leverage OER in your classroom.

It seems unlikely that individual institutions, acting independently and already having collections, will be able to resolve further complex issues of sustainable development of OT.

An indispensable condition for the development of institutional projects for the creation and publication of OT is the partnership of libraries with teachers.

An illustration of one of the DLP services is an example at the Massachusetts Institute of Technology (MIT) Library. The subject librarians of MIT work closely with faculty to help them identify open educational resources that they can use instead of requiring students to purchase textbooks (Marcum, Schonfeld, \& Thomas, 2015).

There are more and more teachers who support open education and how authors create texts for open textbooks or review them. V. Rolfe \& B. Pitt (2018) note that improving the 
learning experience for students was a top reason for academics to have published learning resources in the past, and a key driver for any potential future learning resource publications. Another important motivation is career development.

However, many authors have concerns over copyright and IPR - particularly in terms of what belongs to them and what belongs to their employing university. There is also a concern about reputational risk of learning resources being misinterpreted or misrepresented by other teachers who use them without fully understanding the context or purpose (Collins \& Stone, 2019).

Despite some communication difficulties resulting from this concern, the Publishing Support provided by DLP services to teachers and staff in creating OT is quite diverse across libraries. But it seems obvious that there are basic services:

- Providing tools \& a platform for creating a textbook;

- Providing consultation and training on publishing workflow;

- Connecting authors to shared community resources for faculty mentors, volunteer editing, \& peer review;

- Helping prepare a print version and coordinating print on demand services;

- Helping after finishing work on the text to share it on the website Open Textbooks.

I presented my vision of the possible roles of teachers and librarians in creating open textbooks in Table 1.

Table 1. University PARTNERSHIP: the role of teachers and librarians in creating open textbooks

\begin{tabular}{|l|l|}
\hline \multicolumn{2}{|c|}{ ROLES } \\
\hline \multicolumn{2}{|c|}{ Teachers } \\
\hline $\begin{array}{l}\text { As authors, they create new content or update } \\
\text { (reprint) the existing one }\end{array}$ & $\begin{array}{l}\text { As information specialists, they support and } \\
\text { develop the OT creation and publishing } \\
\text { infrastructure }\end{array}$ \\
\hline $\begin{array}{l}\text { As teachers, they decide which book is right } \\
\text { for their students and their course }\end{array}$ & $\begin{array}{l}\text { As publishers, they provide digital publishing } \\
\text { services, including registration of publications } \\
\text { (ISBN, DOI) }\end{array}$ \\
\hline $\begin{array}{l}\text { As teachers and authors, they adapt the content } \\
\text { of others to their own needs (upon the } \\
\text { availability of Creative Commons Attribution- } \\
\text { NonCommercial-ShareAlike 4.0 License (CC } \\
\text { BY 4.0) }\end{array}$ & $\begin{array}{l}\text { As educators, they contribute to the } \\
\text { development of the information culture of } \\
\text { students and teachers; provide consultation and } \\
\text { training on publishing workflow }\end{array}$ \\
\hline As reviewers, they conduct scientific expertise & $\begin{array}{l}\text { As creative project managers, they popularize } \\
\text { OER and OT }\end{array}$ \\
\hline & $\begin{array}{l}\text { As community organizers, they unite DLP } \\
\text { practitioners among publishing libraries to } \\
\text { develop competencies, learn best practices and }\end{array}$ \\
\hline
\end{tabular}


In addition to teachers, the strategic institutional partners of libraries in creating OT are: IT services, university press, students, open education support services, campus independent bookstores, etc.

In publications that cover the topic of library initiation and support for OER and OT projects, librarian positions have different target titles: Director of Learning Resources, Library Services Educational Specialist, Network and Library Administrator, Library Services Coordinator, Information Communication Manager, Project Manager, Subject Librarian, Expert Librarian, Librarians/Illustrators, Technical Services Managers and others.

Hopefully, the results of this study will allow to start discussions in Ukraine and other countries of Eastern Europe regarding open textbooks and the role of university libraries in their creation and support. So far, Ukrainian libraries have not received mandates for creating open textbooks or other open educational resources.

Most likely, this area of activity of university libraries, which are actively forming the digital infrastructure of science and education, will not be addressed at the national level. But the achievements of Ukrainian libraries prove that it is already possible to start dealing with these issues at the institutional level. And let it be only 2-3 libraries in the country, but these will be the first steps that set the speed up.

The pursuit of social justice is part of the mission of libraries. Therefore, the possibility of eliminating systemic inequalities in access to academic resources makes us constantly look for new ways and initiate new projects in the development of information support for students, teachers and scientists. And now it is time for Open Textbook.

In Ukraine, which has 19 universities that have been displaced since 2014 from the temporarily occupied territories of Donetsk and Lugansk regions, as well as the Autonomous Republic of Crimea, the situation with providing libraries and bookstores with modern textbooks is especially tense. And after the restoration of peace in the Donbass, it is open literature that will contribute to improving the cultural and educational landscape of the region.

In addition, libraries participating in projects for the creation and accessibility of free open textbooks will expand educational prospects for people with disabilities.

Given the above, I would like to have hope that the libraries of Ukrainian universities in partnership with the entities interested in OT publications will start with focus group survey and interviews with students and their own scientists. This will provide a better understanding of local pressures and priorities for the production of academic resources. Perhaps the relevant question would also be how OT production can contribute to broader institutional strategies in open education: improving the students' education conditions, educational prospects for people with disabilities, knowledge sharing, development of staff and professional pedagogical qualifications.

\section{Conclusions}

The development of the digital infrastructure of science and education, global projects of open knowledge today allows fixing 3 types of publishers: commercial publishers, society publishers, library publishers.

University libraries around the world position themselves as a platform for innovation in the field of education, research, knowledge sharing in a global context. And today, the global practice of Scholarly Communication has enough evidence that the functions of the Library, lost in the course of evolution, as a Knowledge Publisher have returned under its "roof" and supplemented the existing function of Knowledge Managers (that is, people responsible for the availability of acquired knowledge, its dissemination and conservation for future generations). 
But it seems that the projects for creation, support and development of open educational resources, incl. Open Textbook, involve mainly the university libraries of the USA, Canada, Great Britain and Australia. At the same time, a clear change in the role and mainstreaming of the libraries of these countries in the landscape of open education is an incentive for many others.

The reflection in the publications of the modern world practice of "DLP services: Open Textbooks" emphasizes that they help to change the learning conditions and life of students, pedagogical practices of teachers by means of free textbooks with an open license, as well as to receive reputation benefits for the university, improving the image of the latter.

Often, OER projects in universities and colleges are initiated from below - by library, faculty, Scholarly Communication or Educational Resources Department, etc., which later as partners are engaged in their implementation and development.

It is this model of initiation and development of Open Textbooks that may be the most successful for libraries in Ukrainian universities. The successes of Ukrainian librarians in supporting digital scholarly communication initiatives and the successful implementation of Open Access support projects (repositories, e-journals, e-conferences) give confidence that they can act as initiators and key partners in creating affordable textbooks.

Most OER projects are using Creative Commons licenses to license their content. Among Creative Commons users, the Attribution-NonCommerical-ShareAlike option is the most popular.

Providing free open textbooks allows:

1) students to save their money; 2) to improve the learning conditions for students, especially for persons with disabilities; 3 ) to save the resources of the libraries and the support services for persons with disabilities; 4) to contribute to the provision of high quality teaching, open resources for teachers; 5) to get reputational benefits for the university.

Reputation benefits for the university are one of the most important elements of its strategy. This is, firstly, the opportunity to strengthen the authority of the university in the practice of open education; secondly, increasing the recognition of its global brand and its reputation as an institution favorable to improving the learning environment of students.

The opportunity to showcase your university worldwide as an institution constantly striving to improve student life far exceeds any potential income.

\section{REFERENCES}

Allen, N. (2010). Open Textbooks: A cover to cover solution: how open textbooks are the path to affordability. In D. Wiley (Ed.) An Open Education Reader. Retrieved from https://openedreader.org/chapter/open-textbooks-a-cover-to-cover-solution-how-open-textbooksare-the-path-to-affordability

Butcher, N., \& Moore, A. (2015). Understanding Open Educational Resources. Retrieved from https://oerknowledgecloud.org/sites/oerknowledgecloud.org/files/2015 Butcher_Moore Understa nding-OER.pdf

Charles C. Sherrod Library. (2019). What if we Could Save Students \$200K this year? Oh wait...we did. Retrieved from https://libraries.etsu.edu/research/oer?fbclid=IwAR34a8HENy8jQM2TP8hnGIPIQcldy6sOVtmMujEiBX0phjD8tuzGD6mfL4

Collins, E., \& Stone, G. (2019). Motivations for textbook and learning resource publishing: Do academics want to publish OA textbooks?. LIBER Quarterly, 29(1), 1-19. doi: http://doi.org/10.18352/lq.10266 
Croteau, E. (2017). Measures of student success with textbook transformations: the Affordable Learning Georgia Initiative. OPEN PRAXIS. 9(1), 93-108. doi: https://doi.org/10.5944/openpraxis.9.1.505

Digital textbook. (2019). Wikipedia.: The Free Encyclopedia. Retrieved from https://en.wikipedia.org/wiki/Digital textbook

Kolesnikova, T. A. (2014). Kommunikatsionnye modeli deyatelnosti bibliotek vyisshey shkoly. Bibliotekovedenie, $\quad 1, \quad 114-122 . \quad$ Retrieved from http://eadnurt.diit.edu.ua/jspui/handle/123456789/4745 (in Russian)

Kolesnykova, T. (2019). University Library as a Publisher: Forming the Digital Landscape of Scientific Communication. Proceedings of the XVIII Intern. Conference "Management of University Libraries", November 28-29, 2018, Minsk, Republic of Belarus. 26-36. Retrieved from http://eadnurt.diit.edu.ua/jspui/bitstream/123456789/11356/1/Kolesnykova.pdf (in Russian)

Kolesnykova, T. O., \& Kliushnyk, I. A. (2015). Publication of scientific periodicals at universities: New challenges, participants, technology. Science and Transport Progress, 6(60), 183-197. doi: 10.15802/stp2015/57105 (in Russian)

KU Libraries. (2019). KU Libraries Announce Textbook Heroes Initiative, Inaugural Cohort. Retrieved from https://lib.ku.edu/news/th-spring19

Levchenko, N. (2018). Vidkrytyi elektronnyi arkhiv - vazhlyvyi chynnyk publikatsiinoi aktyvnosti naukovtsiv. Bibliotechnyi visnyk, 5, 3-7. Retrieved from http://bv.nbuv.gov.ua/doc/bv_2018_5_3 (in Ukrainian)

Library Publishing Coalition. (n.d.). Retrieved August 3, 2019, from https://librarypublishing.org/resources/

Lippincott, S., Schlosser, M., Ballard, H., \& Maron, N. (Eds). (2018). Library Publishing Curriculum. Retrieved from https://educopia.org/deliverables/library-publishing-curriculum

Marcum, D., Schonfeld, R. C., \& Thomas, S. (2015). Office of Scholarly Communication: Scope, Organizational Placement, and Planning in Ten Research Libraries. Ithaka S+R. doi: https://doi.org/10.18665/sr.275206

McGrath, T. (2018). Library is the new publisher: Establishing workflows for library-based open educational resource production programs in post-secondary institutions across Canada and the United States. Retrieved from https://summit.sfu.ca/item/18751

McCready, K., \& Molls, E. (2018). Developing a Business Plan for a Library Publishing Program. Publications, 6(4), 42. doi: https://doi.org/10.3390/publications6040042

Ministry of Education and Science, Youth and Sports of Ukraine. (2012). Nakaz Pro zatverdzhennya Polozhennya pro elektronni osvitni resursy (No 1060). Retrieved from https://zakon.rada.gov.ua/laws/show/z1695-12(in Ukrainian)

Open Textbooks Matter. (n.d.). Retrieved August 3, 2019, from https://open.umn.edu/opentextbooks/about

Open Textbook Network. (n.d.). Retrieved August 3, 2019, from https://www.facebook.com/opentextbooknetwork/ 
Open Textbook Network. (2019). Apply for a Certificate in OER Librarianship. Retrieved from http://research.cehd.umn.edu/otn/oer-cert/)

Pitcher, K. (2014). Library Publishing of Open Textbooks: The Open SUNY Textbooks Program. Against the Grain, 26(5), 22-24. doi: https://doi.org/10.7771/2380-176X.6844

Raju, R. (2016). Not a knee-jerk reaction: openness - a UX imperative. IFLA WLIC 2016 - Columbus, $\mathrm{OH}$ - Connections. Collaboration. Community in Session 136 - Social Science Libraries with Asia and Oceania. Retrieved from http://library.ifla.org/1355/1/136-raju-en.pdf

Rhode Island College Adams Library. (2019). Open Textbook Workshop \& Textbook Review. Retrieved from https://www.facebook.com/events/918188115212120/

Rolfe, V., \& Pitt, B. (2018). Open textbooks - an untapped opportunity for universities, colleges and schools. Insights, 31: 30, 1-6. doi: http://doi.org/10.1629/uksg.427

Schmolling, R. (2015). Agents of the Publishing Chain: From Libraries as Academic Publishers to Libraries as Publishers in eScience and Digital Humanities. IFLA Library. Retrieved from http://library.ifla.org/1164/1/187-schmolling-en.pdf

Serbin, O., \& Kulyk, Y. (2019). Professional Development of Librarians due to the Necessity of Qualitative Changes of the Branch. Ukrainian Journal on Library and Information Science, 3, 5670. https://doi.org/10.31866/2616-7654.3.2019.169668) (in Ukrainian)

SPARC Europe. (2019). Open Education. Retrieved from https://sparceurope.org/what-we-do/openeducation/

SPARC Europe. (2019). What are Open Educational Resources (OER)? Retrieved from https://sparceurope.org/what-we-do/open-education/open-educational-resources/

Sutton, S., \& Chadwell, F. (2014). Open textbooks at Oregon State University: A case study of new opportunities for academic libraries and university presses. Journal of Librarianship and Scholarly Communication, 2(4). doi: http://doi.org/10.7710/2162-3309.1174

Tarkowski, A., Sitek, M., Strycharz, J., Vuorikari, R., \& Castaño Muñoz, J. (2019). Methodological guide for implementation and evaluation of open e-textbook programs. doi: https://doi.org/10.2760/949380 . Retrieved from https://publications.jrc.ec.europa.eu/repository/bitstream/JRC115866/jrc115866_methodological_ guide_final.pdf

The World Bank. (2019). World Bank Country and Lending Groups: Country Classification. Retrieved from https://datahelpdesk.worldbank.org/knowledgebase/articles/906519

Thomas, Wm. J., \& Bernhardt, B. R. (2018). Helping Keep the Costs of Textbooks for Students Down: Two Approaches. Technical Services Quarterly, 35(3), 257-268. doi: https://doi.org/10.1080/07317131.2018.1456844

Todorinova, L., \& Wilkinson, Z. (2019). Closing the loop: Students, academic libraries, and textbook affordability. Journal of Academic Librarianship. 45(3), 268-277. doi: https://doi.org/10.1016/j.acalib.2019.03.010

Volodin, B. F. (2002). Vsemirnaya istoriya bibliotek. SPb.: Professiya (in Russian) 


VTLibraries. (2016). Open Education: What's the Impact? Retrieved from
https://www.youtube.com/watch?v=sSkffgT5DTg\&list=PLWRE6ioG4vdZjdQ_R475jBKmWCX
JQ4psq\&index=16\&t=0s

University of Minnesota Libraries. (2019). Publishing Services. Retrieved from https://www.lib.umn.edu/publishing

Watkinson, C. (2014). The university as publisher revisited. Insights, 27(2), 181-185. doi: http://doi.org/10.1629/2048-7754.131

КОЛЕСНИКОВА Т. О.

Науково-технічна бібліотека, Дніпровський національний університет залізничного транспорту імені академіка В. Лазаряна (Дніпро, Україна), e-mail lib@b.diit.edu.ua, ORCID 0000-0002-4603-4375

\section{РОЛЬ БІБЛІОТЕК ЯК ВИДАВЦІВ У ЛАНДШАФТІ ВІДКРИТОЇ ОСВІТИ: ВІДОБРАЖЕННЯ СУЧАСНОЇ СВІТОВОЇ ПРАКТИКИ OPEN TEXTBOOKS}

Мета. Дослідження спрямовано на вивчення досвіду університетських бібліотек різних країн в роботі з відкритими підручниками (Open Textbook, OT) i розгляд перспектив створення аналогічного пілотного проекту в Україні. Методи. Проаналізовано світові публікації (журнали, книги, доповіді конференцій, пости в соціальних мережах) в області Library and Information Science, присвячені ролі бібліотек в підтримці ОТ та опубліковані з 2014 р. Вивчалися аспекти того, що служби підтримки публікацій, а саме ОТ, є областями з великим потенціалом для майбутнього розвитку академічних / університетських бібліотек. Результат. Представлені численні докази того, що найбільший розвиток тема бібліотеки як видавця в підтримці ОТ має в університетах і коледжах економічно розвинених країн, особливо в США, Канаді, Австралії, Великобританії. Були визначені бібліотечні стратегії по проектам ОТ. Автором уточнено характер ініціатив і партнерства бібліотек в підтримці ОТ, а також базові послуги і ролі бібліотек в даних проектах. Висновки. Сьогодні світова практика наукових комунікацій має досить фактів того, що загублені в процесі еволюції функції Бібліотеки як Видавця знань повернулися під іiі "дах" і доповнили існуючу функцію Менеджерів знань. Послуги цифрового бібліотечного видавництва (Digital Library Publishing) в підтримці ОТ допомагають змінювати умови навчання і життя студентів (в т.ч. осіб з обмеженими можливостями), педагогічні практики викладачів за допомогою безкоштовних підручників із відкритою ліцензією, а також отримувати репутаційні вигоди для університету, покращуючи його імідж. Можливість усунення системної нерівності в питаннях доступності академічних ресурсів підвищує значущість і змінює роль бібліотек у відкритій освіті. Успіхи українських бібліотекарів у підтримці цифрових ініціатив наукової комунікації та успішна реалізація проектів підтримки Відкритого Доступу (репозитарії, е-журнали, е-конференції), дають впевненість, що вони можуть виступити ініціаторами і ключовими партнерами у створенні доступних підручників

Ключові слова: відкриті підручники; доступність підручника; відкрита освіта; бібліотека як видавець; послуги; цифрове бібліотечне видавництво; бібліотеки університетів; Україна 